\title{
Consumers' attitudes towards modern solutions in the retail trade ${ }^{1}$
}

\author{
Grzegorz Maciejewski $i^{2}$
}

\begin{abstract}
The aim of the article is to present consumer attitudes in Poland in respect of modern solutions in the retail trade and the influence which these attitudes have on their behaviour in the market. The considerations were conducted using methods of logical inference, based on a critical analysis of available derivative sources and conclusions from quantitative research conducted on a sample of 1.075 consumers. In order to analyse more deeply the research results a cluster analysis was conducted using one of the hierarchical methods - the Ward's method.

Respondents' attitudes towards modern solutions in the retail trade are generally positive. However they are not always recognized by them. A large percentage of respondents declared that they are not acquainted with particular forms of modern retail trade (mostly Beacon, PSS or RIFID systems). They were mostly consumers from the 'retreated skeptics' group, in other words the elderly with basic or vocational education from small towns and villages. The research findings presented may be used by trade enterprises in order to answer to the identified need of consumers from generation $\mathrm{Z}$ and to set out the direction of the technological education of consumers and increase the availability of particularised solutions.
\end{abstract}

Keywords: consumers' attitudes, consumers' behaviour, consumers' generations, the retail trade, quantitative research, cluster analysis.

JEL codes: C10, D12, M31.

\section{Introduction}

Many contemporary visionaries such as Yonsji Masudo, Tadao Umesamo, Kenichi Koyama - in Japan, and Simon Nory and Alain Minc in Europe already predicted in the 1960 s that 21 st century civilisation will not be a material civilisation symbolised by enormous constructions, but it will be an invisible civilisation, information civilisation (Ito, 1980). Highly developed societies in building it as defined by the term 'information societies', will centre most

\footnotetext{
${ }^{1}$ Article received 18 December 2017, accepted 9 May 2018.

${ }^{2}$ University of Economics in Katowice, Market and Consumption Department, ul. 1 Maja 50, 40-287 Katowice, Poland, grzegorz.maciejewski@ue.katowice.pl.
} 
of their efforts on generating, storing, distributing, receiving and using information (Goban-Klas \& Sienkiewicz, 1999; Biswas \& Roy, 2018). It is apparent from the perspective of the second decade of the 21 st century that these words were prophetic. The technological and economic progress, unprecedented so far, accompanying the social changes, transformed contemporary man into a creature defined by the term 'homo interneticus' - a working, buying, relaxing man, who pays in virtual reality.

Currently the key target group for many manufacturers and sellers is being constituted by Y generation consumers (Foscht, Schloffer, Iii, \& Chia, 2009), born in the years 1981-1999 (Bolton et al., 2013), defined as well as "Millenials", "searching generation", "Internet generation" (Littman, 2008; Van den Berch \& Behrer, 2012) as well the Z generation coming behind them, also called "screen generation" by sociologists. In case of the $\mathrm{Y}$ generation and the youngest $\mathrm{Z}$ generation we may observe that the boundaries between them tend to overlap. Some authors state that the $Z$ generation consists of persons born after 1955 (Seppanen \& Gualtieri, 2012), whereas others that they are all born after 2000 (Richard K. Miller and Associates, 2011), although there is no consensus in Polish and foreign literature with reference to the scope of these years (Gołąb-Andrzejczak, 2014). What is significant, however, is that these are persons born in the years of information technology (Knežević \& Delić, 2017). The Internet was present in their lives since their youngest years as well as the virtual world and technological gadgets. They are called 'welfare kids' equipped with their smart-phones and tablets. Their greatest skill, as can be seen from the above, is due to their birth in the years of IT boom. Thanks to that they are perfectly oriented in various kinds of technical novelties and their entire life revolves around a virtual world.

New generations of consumers require new strategies and forms of selling from retail trade enterprises (Maciejewski, 2016; Samoggia \& Nicolodi, 2017). It does not concern only new trade formats, offering goods and services searched by consumers at a relevant time, place and at a possibly acceptable price, but it also concerns the implementation of technological solutions facilitating consumers to make a decision and do their shopping (Kushwaha, Ubeja, \& Chatterjee, 2017). We need to pose a question here if the proposed solutions, such as self-service checkouts, self-service scales or intelligent shopping trolleys are accepted by consumers? How common can this acceptance be? Which groups of consumers use each solution and which ones are rather distant or do not know them at all?

This article is empirical. Its objective is the demonstration of identified attitudes of contemporary consumers towards contemporary solutions in retail trade and transferring these attitudes to their market behaviours. The hypothesis which was verified during the research assumed that consumers' attitudes towards modern solutions in retail trade are positive, however their strength (power) is conditioned by demographic and the personality features of respondents. The source background of the considerations presented is constituted by source literature 
and the author's primary research conducted within the research project titled "Retail trade and services in Poland - consumer's perspective" implemented in the years 2016-2017. This paper is organised as follows: section 1 deals with the literature review of the impact of attitudes on consumer behaviour and modern solutions in the retail trade; section 2 describes the data and methodology used; section 3 presents the results of the research and the procedure of grouping the consumers studied in terms of their attitude to modern solutions in the retail trade. The last section includes a summary of the main results of the paper.

\section{Theoretical framework}

\subsection{Attitudes in consumer behaviour}

Consumers' attitudes have been the subject of marketing research for many years. The reason for researchers' interest is the possibility of shaping attitudes by means of marketing instruments and the influence of such shaped attitudes on consumer market behaviour. The source literature may even present the view that behaviour may be somewhat the "end product" of attitude and although the relationship between attitudes and behaviours is not so evident and simple the influence of attitudes on behaviour is an unquestionable fact (Falkowski \& Tyszka, 2009; Hoyer, MacInnis, \& Pieters, 2013).

While conducting the search for source literature we may encounter many varied definitions of the term "attitude". The differences among them are the result of different theoretical concepts approved by authors. In addition the fact to which aspect a given author pays attention is very significant (Albarracin \& Shavitt, 2018). Following Rudnicki (2012) we may distinguish three groups of definitions of attitudes. These are:

1. Definitions referring to a behaviourist tradition or psychology of learning. They define attitudes as some kind of dispositions for behaving in an organised way. Moreover they focus on a person's behaviour and their reactions towards objects (including social ones).

2. Definitions referring to a sociological concept. The attitude is defined here as a relatively permanent emotional or evaluating attitude to an object or tendency for the attitude to occur and it may be positive, negative or neutral. This group of definitions focuses primarily on the observer's attitude towards the object.

3. Definitions referring to psychological cognitive theories. They emphasise that the attitude is related not only to specific behaviour or attitude, but also to cognitive elements.

Marketing literature most frequently presents definitions of attitude referring to a sociological concept. Such understanding of attitude was assumed in this article as well. 
Everything and everyone may be the object of attitude: from material and abstract things, through people or groups of people, to ideas, behaviours, religion, culture, etc. (Wojciszke, 2011). The belief prevailed among researchers for many years that attitudes had to comprise three elements:

- cognitive (what a person thinks about the object of attitude);

- emotional (what a person feels towards the object);

- behavioural (how a person behaves towards the object of attitude).

It was assumed as well that these elements must be coherent. Currently it is thought that although attitudes must comprise all three elements they do not have to be coherent with each other (Stasiuk \& Maison, 2014). Otherwise there are such attitudes which are predominantly based only on one of these elements. It means that attitudes are formed as a result of the advantage of one element over others. Other elements may not be identified at all. It sometimes occurs that a consumer likes or dislikes a given product, but when asked for reasons they cannot specify them. On the other hand, there may occur a situation, in which the same consumer is familiar with opinions about a given product, however, this product does not evoke any emotions. Another time a consumer does not feel any emotions nor any beliefs, in spite of his specific behaviour (Trojanowski, 2013; Taranko, 2017).

Despite different approaches to the very notion of attitude researchers agree that attitudes have two significant features: mark and strain (strength). Attitude mark indicates that it is positive (+), negative (-) or neither positive - nor negative (0), or indifferent in a situation when a person does not agree with positive or negative statements towards the object of attitude or is ambivalent in a situation when a person agrees with both positive and negative statements (Stasiuk \& Maison 2014). The person's approach to the object of attitude is expressed in the form of emotions, feelings, possessing beliefs evaluating this object or in a form of tendency to a specific behaviour. It is necessary to become aware of a certain relation between one's own situation and the object of attitude to observe a positive or negative attitude in a given person.

The strength of attitude defines, in turn, to what extent the attitude is positive or negative, that is, if it is weak or strong. Both a mark and the strength of attitude define its regulatory functions. Hence theoretically dependant on whether the given attitude is negative or positive, a person should demonstrate reactions of avoiding an object (in case of a negative attitude) or wish to acquire it (for a positive attitude). However the strength of attitude is reflected in the conditions of its modification. A relatively weak attitude easily succumbs to changes, a strong attitude, on the other hand, definitely succumbs in a more difficult way.

The properties of attitude demonstrated prove its subsequent characteristic feature, namely its considerable durability (Maison, 2004; Rudnicki, 2012). Attitudes are relatively permanent and easily succumb to changes in time. The durability of attitude is apparently related to its strength. Although attitudes are permanent it does not mean that they cannot be changed. 


\subsection{Contemporary solutions in trade as the object of attitudes}

Commercial companies are supported to an ever greater degree by modern technologies, which may not only modify the functioning of the company but also influence the relations with consumers - customers of the company (Luceri, Sabbadin, \& Zerbini, 2017). They may serve to accelerate the process of customer service or eliminate their difficulties with shopping, related to finding a product or finding information about a product in a retail outlet or preventing discrepancies between the price at a till and the price on a shop shelf. The solutions modifying the course of the process of customer service comprise (Lipowski, 2010; Kucharska, 2014):

- self check-out systems (self check-out, self-service scales, self-service product scanning systems);

- shopping trolleys with a price scanner allowing a product price to be checked and to add up the value of goods in a trolley, the so-called Personal Shopping System - PSS;

- shopping trolleys equipped with a RFID (Radio Frequency Identification) system enabling to scan product prices placed in a trolley and to pay for all the shopping at once without the need to take out all the products at a till;

- intelligent shopping trolleys with an LCD display enabling the navigation in a shop, displaying information about current promotions, location of complementary products with reference to the ones already purchased or displaying a shopping list recorded on a smart-phone;

- intelligent shopping trolleys equipped with a Beacon system sending a radio signal transferring, directly via Bluetooth connection, information about a product just being passed by or current promotions on a customer's smart-phone;

- radio trolleys ("talking" shopping trolleys emitting through an audio system recommendations and advertisements of products situated near the customer);

- vending machines offering drinks, snacks, cigarettes, etc.;

- reverse vending machines accepting returnable packaging (bottles, cases, etc.);

- electronic queuing systems enabling the provision of a ticket and a relaxed await for one's turn in accordance with the rule "first come first served" FCFS;

- mobile shopping assistance (devices displaying the total value of shopping, allowing for the faster location of a product on the shelves, indicating any saving within a given promotion);

- virtual advisers appearing on the websites of shops, bank, offices, institutions. Modern technological solutions of this kind will decide the future formats of retail shops and the market success of commercial companies. In the opinion of researchers from Planet Retail RNG within a couple of years more and more sellers will be investing in technologies allowing interaction with customers, in 
particular just before making a decision about a purchase and in mobile payment systems allowing customers to make payments via a smart-phone (Planet Retail RNG, 2015). So that new technologies are accepted by customers they must be not only safe and provide privacy, but they also have to be comfortable, easily used and provide additional benefits in a form of new ways of rewarding loyalty based on personalization and digitalization.

\section{Empirical methodology and data description}

Empirical research, the result of which was used in this article, was conducted in January and February 2017 within the afore-mentioned research project entitled "Retail trade and services in Poland - consumer's perspective" implemented in the years 2016-2017 and financed by Ministry of Science and Higher Education. The main objective of the project was the identification of purchasing behaviour and consumer opinions on the functioning of commercial and service outlets in Poland (traditional and online). The part of research conducted within the project concerned consumers' attitudes in relation to technological solutions used currently in retail outlets.

The research was conducted among non-randomly selected individual consumers. The decision on the selection of a non-random choice for the sample was mostly made due to a lack of a relevant selection report and the necessity to limit research costs. The survey methodology used in the research were online survey techniques. Adults who are the inhabitants of the Silesian province were qualified for the sample, and who were regularly shopping and using consumer services ${ }^{3}$ and they responded to the invitation from the researchers and filled in a questionnaire online submitted through the research platform: surveymonkey (www.surveymonkey.com). The questionnaire contained 19 content-related questions and 16 specific. ${ }^{4}$ The majority of the content-related questions were formulated in the form of ordinal, bipolar, 7-degree scales. Reliability estimates of the scales used were conducted by means of calculating Cronbach's alpha co-efficient. ${ }^{5}$ In addition questions in a form of boards and dichotomous, filtration questions were applied. Content-related questions

\footnotetext{
${ }^{3}$ Regular shopping was assumed to be done in commercial and service institutions at least once a month.

${ }^{4}$ Including 11 dichotomous questions allowing knowledge of the respondents' attitude, to novelties, fashion, forms of spending free time, place of spending free time, care about the natural environment, timeliness of realizing obligations, healthy eating or care about one's fitness.

${ }^{5}$ The data analysed in this article were collected by means of two of our own scales defining the respondents' attitudes in relation to modern technological solutions in retail trade. The first of them achieved the coefficient value $\alpha=0.854$. The second, $\alpha$ value $=0.714$. If we assume that the acceptable coefficient level $\alpha>0.7$, as suggested by Nunally and Bernstein (1994), then both scales may be regarded as reliable.
} 
were relevant to the research objectives and served to for the identify the attitudes and purchasing behaviours of respondents, as well as for the collection of respondents' opinions on the functioning of service and commercial outlets. The specifics enabled the provision of characteristics for the sample studied regardless of the demographic, economic, social and personality features of the respondents. The intention of the researchers was to achieve a sample of 1.200 consumers from the Silesian province. However as a result of the formal verification of the research material obtained, 1.075 completely and correctly completed questionnaires were qualified for the analyses.

Women were slightly more in the sample, constituting $53.2 \%$ of respondents. In general the respondents were young people aged 18-24 (30.3\%) and aged 25-34 (23.1\%). Thus, in accordance with categorization of generations by Brosdahl and Carpenter (2011), they represented the afore mentioned Y and $\mathrm{Z}$ generations. Generation X respondents, currently aged 35-54 constituted almost $30 \%$ of respondents in the sample. However baby boom generations (Boomers - born in the years 1946-1960) and the so-called silent generation (born before 1946) represented respectively $8.2 \%$ and $8.8 \%$ of respondents in the sample. Over $45 \%$ of respondents had completed secondary education, almost $40 \%$ higher education, however nearly $15 \%$ possessed only primary education and basic vocational education. People living in towns or cities prevailed among respondents (84.5\%) where the most numerous group was made up of respondents from cities amounting from 101 to 200 thousand inhabitants. Country dwellers participating in the study constituted $15.5 \%$ of the respondents. The study participants, when asked about their evaluation of the financial situation of their household, most frequently admitted that it was good or average (respectively $52.8 \%$ and $33.5 \%$ ). A bad or very bad situation was declared by $4.2 \%$, however a very good one - by $8.8 \%$ of respondents. ${ }^{6}$

Apart from structure indicators, correlation coefficients and position measures, cluster analysis was used for the description of the research results. Numerous applications of cluster analysis are mentioned by Walesiak (2004, pp. 344-347). The objective of the application of cluster analysis was willingness to group and describe the consumers studied in accordance with their attitude to modern technological solutions used in the retail trade. For this purpose one of hierarchical agglomerative methods - Ward's method was used and applied with squared Euclidean distance. ${ }^{7}$ The programme IBM SPSS Statistics 24 was used in all calculations.

${ }^{6}$ In the research the notion of a very good financial situation was adopted from the statement "We can afford everything"; good - "we can afford some luxury goods"; average - "we must plan bigger expenses", bad - "we can afford only the basic needs", very bad - "we cannot afford the basic needs".

${ }^{7}$ The variance analysis is used in Ward's method to estimate distances among clusters. Position measure among objects (clusters) is intra-group variance for the group arising from the combination of these objects (clusters). This method aims at minimization of the square sum of 


\section{Results and discussion}

While analysing the results of the research we may observe that the interviewed consumers have mostly a positive attitude towards all modern solutions in the retail trade presented to them. It is most noticeable in case of reverse vending machines accepting returnable packaging, self checkouts or electronic queuing systems, towards which over $80 \%$ of respondents declared a positive attitude. The respondents had the most negative and neutral attitudes towards virtual advisers attempting to replace on the websites of shops, banks or institutions a personal contact with a shop assistant or a clerk (Table 1).

Table 1. The respondents' emotional attitude towards modern solutions in retail trade $(N=1,075)$

\begin{tabular}{|l|r|r|r|c|c|c|c|}
\hline \multirow{2}{*}{ Specification } & \multicolumn{2}{|c|}{ Attitude (in \%)* } & \multirow{2}{*}{ M } & Me & Mo & SD \\
\cline { 2 - 7 } & $\begin{array}{c}\text { nega- } \\
\text { tive }\end{array}$ & $\begin{array}{c}\text { neu- } \\
\text { tral }\end{array}$ & $\begin{array}{c}\text { posi- } \\
\text { tive }\end{array}$ & M & & & \\
\hline Self checkouts & 15.8 & 9.9 & 73.3 & 1.4846 & 2 & 3 & 1.8763 \\
\hline Self-service scales & 9.8 & 8.5 & 81.7 & 1.8224 & 3 & 3 & 1.6202 \\
\hline $\begin{array}{l}\text { Shopping trolleys equipped } \\
\text { with PSS system }\end{array}$ & 9.1 & 11.2 & 79.7 & 1.8463 & 3 & 3 & 1.6099 \\
\hline $\begin{array}{l}\text { Intelligent shopping trolleys } \\
\text { with a display or Beacon } \\
\text { system }\end{array}$ & 13.6 & 13.1 & 73.3 & 1.5197 & 2 & 3 & 1.7711 \\
\hline $\begin{array}{l}\text { Intelligent shopping trolleys } \\
\text { equipped with RFID system }\end{array}$ & 13.7 & 12.6 & 73.7 & 1.5407 & 2 & 3 & 1.7841 \\
\hline Vending machines & 13.9 & 14.4 & 71.7 & 1.3236 & 2 & 3 & 1.7841 \\
\hline $\begin{array}{l}\text { Reverse vending machines ac- } \\
\text { cepting returnable packaging }\end{array}$ & 6.3 & 10.9 & 82.8 & 1.9306 & 3 & 3 & 1.4277 \\
\hline $\begin{array}{l}\text { Electronic queuing systems } \\
\text { (FCFS) }\end{array}$ & 10.8 & 9.0 & 80.2 & 1.7603 & 3 & 3 & 1.6708 \\
\hline Virtual advisers & 24.8 & 21.8 & 53.4 & 0.6648 & 1 & 3 & 1.9629 \\
\hline
\end{tabular}

* Measured on a 7-degree scale, where: -3 - a definitely negative attitude, and $+3-$ a definitely positive attitude. A negative attitude is a sum of indications from -3 to -1 , neutral 0 , and a positive attitude denotes indications from +1 to +3 .

Where: $\mathrm{M}$ - arithmetic mean, $\mathrm{Me}$ - median, $\mathrm{Mo}$ - modal value, mode, SD - standard deviation.

Source: Own research.

deviations inside clusters. Cluster differentiation measure towards average values is ESS (Error Sum of Squares), also called the sum of squared errors. Ward's method is considered very effective, although it aims at creating clusters of small size. Walesiak (2009) and Migdał-Najman \& Najman (2013) write more on the method of cluster analysis. 
Self service scales, self checkouts and vending machines may be considered modern solutions in retail trade and were the most known to the respondents. Their acquaintance is almost commonplace. The declarations of the awareness of these solutions during the research were given by nearly $100 \%$ of respondents (Table 2). Considerable awareness of a given solution by consumers may, although not necessarily have to mean that they make use of such a solution to a considerable degree. Thus in case of self service scales the declarations of awareness of such a solution were given by $97.7 \%$ of respondents, and the declaration of using it by $81.6 \%{ }^{8}$ However in the case of a virtual adviser $84.0 \%$ of respondents admitted that they know such a solution, but only $23.7 \%$ use it - Table 2.

Table 2. Awareness and use of modern solutions in retail trade - the respondents' declarations $(N=1,075$, in $\%)$

\begin{tabular}{|l|c|c|c|c|c|}
\hline \multirow{2}{*}{\multicolumn{1}{|c|}{ Specification }} & \multicolumn{4}{c|}{ I know - } & \multirow{2}{*}{ I use } \\
\cline { 2 - 5 } & $\begin{array}{r}\text { I do not } \\
\text { use but I } \\
\text { intend to }\end{array}$ & $\begin{array}{c}\text { I do not } \\
\text { use }\end{array}$ & $\begin{array}{c}\text { I do not } \\
\text { use and } \\
\text { I do not } \\
\text { intend to }\end{array}$ & $\begin{array}{c}\text { I not } \\
\text { know }\end{array}$ \\
\hline Self checkouts & 70.9 & 4.4 & 15.9 & 6.1 & 2.7 \\
\hline Self-service scales & 81.6 & 5.4 & 6.9 & 3.8 & 2.3 \\
\hline $\begin{array}{l}\text { Shopping trolleys equipped } \\
\text { with PSS system }\end{array}$ & 8.1 & 13.9 & 13.3 & 4.8 & 59.9 \\
\hline $\begin{array}{l}\text { Intelligent shopping trolleys } \\
\text { with a display or Beacon system }\end{array}$ & 3.8 & 12.0 & 11.4 & 5.6 & 67.0 \\
\hline $\begin{array}{l}\text { Intelligent shopping trolleys } \\
\text { equipped with RFID system }\end{array}$ & 3.6 & 12.2 & 11.0 & 4.6 & 68.6 \\
\hline Vending machines & 62.6 & 6.4 & 20.3 & 7.7 & 3.0 \\
\hline $\begin{array}{l}\text { Reverse vending machines ac- } \\
\text { cepting returnable packaging }\end{array}$ & 29.3 & 17.4 & 26.3 & 6.4 & 20.6 \\
\hline $\begin{array}{l}\text { Electronic queuing systems } \\
\text { (FCFS) }\end{array}$ & 74.1 & 6.0 & 8.1 & 5.8 & 6.0 \\
\hline Virtual advisers & 23.7 & 12.4 & 34.2 & 13.7 & 16.0 \\
\hline
\end{tabular}

Source: Own research.

${ }^{8}$ This observation is confirmed as well by the Spearman's rank correlation coefficient and Kendall's tau b coefficient obtained which amounted, in the case of self service scales $r_{s}=0.387$; $\tau_{b}=0.347,(p \leq 0.01)$. The significant bilateral correlations were observed as well in the case of: self checkouts $r_{s}=0.569 ; \tau_{b}=0.496(p \leq 0.01)$; vending machines $r_{s}=0.468 ; \tau_{b}=0.401(p \leq 0.01)$; FCFS $r_{s}=0.346 ; \tau_{b}=0.308(p \leq 0.01)$; virtual advisers $r_{s}=0.419 ; \tau_{b}=0.345(p \leq 0.01)$ and reverse vending machines accepting returnable packaging $r_{s}=0.216 ; \tau_{b}=0.184(p \leq 0.01)$. 
On the other hand lack of awareness of a given convenience or its non-use does not always denote that a consumer has a negative attitude to it. Sometimes the very image of a specific solution by consumers and the benefits it brings causes positive reactions among them. Such solutions as trolleys with a scanner, trolleys equipped with RFID system, trolleys with a display or Beacon system, despite the fact that they are not known to nearly two thirds of potential users are positively perceived by almost three quarters of respondents (Tables 1 and 2). In this context it is also worth focusing on the variant of the response "I know - I do not use, but I intend to" - Table 2. Some consumers do not use a given solution because there are no such opportunities in their commercial outlets and they only observed it while being abroad or browsing through the press or the Internet. It is, then, a significant signal for the owners of retail shops to implement new solutions more extensively, in particular the ones which facilitate a and digital-savvy consumer to do the shopping. Such activities could become an important element of competitive advantage for them.

For the purpose of developing the analysis of the research results a procedure of grouping the consumers studied in terms of their attitude to modern solutions in retail trade was conducted. The afore-mentioned Ward's agglomerative method - one of the hierarchical methods of cluster analysis was used here. As a result of using this method a dendrogram was obtained, reflecting a hierarchical structure of a set of objects due to a decreasing similarity between them. The hierarchy obtained allows a definition of a mutual position of clusters and objects included in them. However the assumed cut-off point allowed the isolation of five relatively homogenous consumer groups.

The first group (cluster I) comprised consumers having a very positive attitude towards all modern solutions in the retail trade demonstrated in the research (the highest percentage of responses +3 or +2 on a 7 -degree scale among all isolated groups). This group of consumers studied was very familiar, among all the isolated groups, with shop facilities equipped with PSS, Beacon, RFID and reverse vending machines accepting returnable packaging. Their familiarity was only slightly worse than the consumers from the fourth group. They were also people who most frequently, among all studied respondents, declared the use or the intention to use such type of devices.

$57.9 \%$ of women and $42.1 \%$ of men were in the first group. No other cluster comprised such a high percentage of women and such a low percentage of men. Analyzing the age structure $32.5 \%$ of consumers aged $18-24$ (Z generation) was in this cluster, 28.9\% aged 35-54 (X generation), 26.8\% aged 25-34 (Y generation). The remaining $11.8 \%$ was constituted by people aged 55-64 (Boomers generation) and aged 65 and more, or the so-called silent generation. The first cluster comprised the highest percentage of consumers with secondary education (48.6\%) and higher education (45.0\% - the most among all analysed clusters). The cluster I comprised the most people from cities of over 200 thousand inhabitants (19.9\%) in relation to other analysed groups. 
The consumers creating this cluster prefer healthy eating (73.0\%) and spending free time outdoors (61.4\%), most preferably in an active way $-75.7 \%$ (the highest percentage among all analysed groups). In addition no other cluster comprised as many people declaring their concern for the natural environment (88.9\%), care about fitness (68.2\%) and enjoying novelties (30.9\%). This is the only group in which the consumers enjoy "a lot going on" have an advantage over the one enjoying peace and quiet. These consumers may be defined by the term active innovators. They constituted a group of $40.1 \%$ of respondents in the sample.

Cluster II (the second group of respondents) is characterised the most by its indifferent attitude to modern solutions in retail trade (the most selected variant "0" on a 7-degree scale), transferred in the case of shopping trolleys equipped with PSS, Beacon and RFID systems into a negative attitude (the most, just after the fifth group with evaluations " -3 "). The familiarity and the willingness to use the facilities may be evaluated as average in comparison with other clusters, lower from the consumers from the first and the fourth group, higher from the respondents from the third and the fifth group.

It is the group in which the greater number of men over women is the biggest (53.8\% of men $-46.2 \%$ of women). This group is mostly made up of people from the X generation (35-54 year olds) - 30.6\% in the cluster, subsequently by people from the $\mathrm{Z}$ generation (18-24 year olds) $-22.6 \%$ and the silent generation ( 65 years old and more) $-18.8 \%$. Cluster II contains the most people with secondary education among all isolated groups. They constitute almost half of the entire group (48.9\%). What is worth emphasizing here is the high participation percentage of consumers with basic vocational education $-22.0 \%$. During the evaluation of their financial situation, $44.1 \%$ of respondents indicated the response "good", $41.9 \%$ - "average". These were the most frequently indicated evaluations in this group. Cluster II was most frequently made up of consumers living in cities of 101-200 thousand inhabitants (30.6\%) and from cities of 51-100 thousand inhabitants (19.4\%).

In cluster II we may observe a slight majority of the 'stay-at-home' over people willing to spend time outdoors $(53.2 \%-46.8 \%)$. Despite the majority in the group of people willing to spend time actively (58.1\%); this group comprised a high percentage of people willing to spend time passively (41.9\%). Only the consumers from the fifth group want to spend time less actively than the consumers from the second group. The people making up cluster II are the ones who most value functionality $(85.5 \%)$, most of all they want to be well-dressed $(82.7 \%)$ - unnecessarily fashionably (17.3\%). They care the least about what others think of them (30.1\%) from all the analysed groups. They do not care too much about their fitness - only $57.8 \%$ of consumers from this group. Only the fifth group is characterized by less care about their own fitness. Only the consumers from the fifth group like novelties less (the second group: $23.2 \%$ of consumers enjoying novelties - the fifth group: $12.8 \%$ ). The consumers mak- 
ing up cluster II may be then defined by the term independent pragmatists. They constituted $17.9 \%$ of respondents in the collected sample.

Cluster III (the third isolated group of respondents). The negative attitudes towards modern solutions in the retail trade are the most noticeable in this group, just after cluster V. The awareness level of facilities offered by retailers is relatively low in this group. A relatively low number of consumers from this group use or intend to use such facilities.

In observing the structure of the third group we may notice that men are in the majority, constituting $53 \%$ of the respondents. Due to the the respondents' age, cluster III has the same percentage of people from the $\mathrm{X}$ generation (35-54 year olds), as well as from the $\mathrm{Z}$ generation (18-24 year olds) $-29.3 \%$ each. The third part is represented by consumers from the Y generation (25-34 year olds) $-22.1 \%$. The third group comprises the most people possessing secondary and higher education (respectively: $43.6 \%$ and $40.9 \%$ ). Cluster III also comprises respondents who, more frequently than in other groups, evaluated their financial situation as average. They constituted $46.7 \%$ of people in cluster III. As far as the place of residence is concerned most people live in cities of 101-200 thousand inhabitants (29.8\%) and cities of 51-100 thousand inhabitants (20.4\%), similar to the respondents in cluster II.

In comparison to the four remaining clusters in many respects consumers making up cluster III are ranked in the middle. It is due to the important attitude of respondents to novelties in respect of the considerations demonstrated. $26.8 \%$ of consumers from this group like novelties, and the mature, familiar solutions are favoured by $73.2 \%$ of respondents. The consumers from group III like novelties more than the respondents from the fifth and the second group, but less than from the first and the fourth group. Consumers from this group do not do anything most frequently nor most rarely in relation to other groups, except for the smallest declared determination among all groups to look fashionably $(8.9 \%)$. These people may be then defined by the term careful realists. They constituted $17.4 \%$ of the investigated sample.

The fourth group of analysed consumers (cluster IV) is characterised by a positive attitude to modern solutions in the retail trade, a slightly lower one compared to the attitudes of the consumers from the first group. It may possibly result from a weaker awareness of these devices compared with the consumers in cluster I, although this awareness is at the higher level than in the second, third and fifth groups. A relatively good knowledge of modern solutions in this group of respondents was reflected in a high percentage of declarations of the use of these facilities in commercial outlets. The consumers forming cluster IV, more frequently than the consumers from other groups, declared the use of self service scales ( $91.4 \%$ of consumers from this group), self checkouts $(91.8 \%)$, FCFS queuing systems (85.2\%), vending machines (82.8\%). The consumers in this group apparently appreciate a personal contact with a shop assistant. It is observed in their attitude to virtual advisers. No other group of 
respondents evaluated this solution with such a small number of responses: "a definitely positive attitude". Only $1.4 \%$ of respondents from this group provided the evaluation +3 on a 7 -degree scale. Moreover, despite the familiarity with this solution by $90 \%$ of respondents from this cluster (the most among all groups), as many as $68.4 \%$ do not use and do not intend to use it in the future.

Women $(55.5 \%)$ were in the majority in the fourth group, similarly to the first group. The structure of education looked similar as well. These were mainly people possessing secondary education (47.4\%) and higher education (44.0\%). Analysing the age structure, in cluster IV there were $37.8 \%$ of consumers aged 18-24 ( $\mathrm{Z}$ generation), 32.1\% aged 35-54 (X generation), $21.3 \%$ aged 25-34 (Y generation). The remaining 8.8\% were people aged 55-64 years old (Boomers generation) and aged 65 and more - Silent generation. With reference to other groups, in cluster IV there were the most people from cities of 101-200 thousand inhabitants (33.5\%).

Cluster IV is formed by the most polychronic consumers among the investigated groups, most frequently performing their duties at short notice (51.4\%). They eat most unhealthily (such declarations were given by $36.1 \%$ - the most among all the groups). Just after the consumers from the first group they were the most open to novelties (28.0\%), willing to spend time actively $(75.0 \%)$, enjoying it when something' is going on (47.1\%) - however, where care about fitness is concerned, not only do the consumers from the first group care about it but also the consumers from the third group. The respondents from the fourth group, the most of all groups, value good style and appearance (20.7\%), just after the consumers from the fifth group, they most desire to look fashionable (21.2\%) These consumers may be then defined as busy conformists. They constituted the second largest group of consumers studied $-20.1 \%$.

The fifth group of consumers (cluster V) is characterised by the biggest scepticism in relation to modern solutions in the retail trade. Expressing their attitude to particular facilities they most frequently, among all isolated groups, marked the response -3 (a definitely negative attitude), and most rarely the response +3 (a definitely positive attitude). This group is characterized as well by the lowest level of familiarity with the proposed solutions, which is notably reflected in their reluctance to use them - the biggest among all isolated clusters. The respondents from this group do not use and do not intend to use not only the solutions appearing in Poland, such as intelligent trolleys, but also the ones present for many years, such as self service scales or vending machines. Thus, 38.3\% of consumers from this group do not use trolleys equipped with a PSS system and do not intend to use them, the Beacon system - 35.4\%, RFID system $-25.1 \%$. In addition, from vending machines $-72.3 \%$, self checkouts $68.1 \%$, reverse vending machines accepting returnable packaging $-58.3 \%$, self checkouts $-49.6 \%$, FCFS - $43.8 \%$. Virtual advisers raise a reluctance as well $60.5 \%$, however in case of this solution the consumers from the fourth group are more sceptical than the consumers from the fifth group. 
Cluster $\mathrm{V}$ is characterised by the smallest gender disproportion among the isolated clusters, for $52.1 \%$ of men and $47.9 \%$ of women were in this group. However such a high percentage of people living in the country $(25.0 \%)$ and in cities of 50-100 thousand inhabitants (22.9\%) was not observed in any of the previous clusters. This group may be also defined as the oldest group among the isolated ones. It is formed equally by the representatives of the Boomers generation and the $\mathrm{X}$ generation (25\% each); the third largest part consumers of the silent generation (18.8\%). This group also seems to be poorly educated among the isolated groups. Despite the advantage of people with secondary education (39.2\%), definitely more people than in other clusters had basic vocational education (29.2\%) and primary education (10.4\%). As far as the subjective evaluation of one's own financial situation was concerned the consumers from the fifth group most frequently evaluated it as average (33.3\%) and good $(31.3 \%)$. What is interesting is that this group comprised the most people describing their financial situation as very good (12.5\%).

The consumers forming cluster $\mathrm{V}$ are definitely the 'stay-at-home' (77.1\%), preferring passive ways of spending free time $(68.8 \%)$ in peace and quiet $(68.8 \%)$ - the highest percentage of all groups. These preferences are also observable in other declarations of people forming the fifth group. It is the only group in which the consumers are in the majority who admit that they do not care about their own fitness (56.2\%) and although they do not care about fitness they most frequently declare healthy eating to be important (77.1\%). What is interesting is that it is a group of consumers which cares most about the opinions of others (45.8\%) and as a result they want, most of all, to look fashionable (22.9\%). They are also the most conscientious of all respondents of doing their tasks before the deadline (77.1\%). They maintain a great distance from novelties. Only $12.8 \%$ of consumers from this group declare that they like novelties, the remaining consumers select what is known and tested $-87.2 \%$. They care least about the natural environment. Such a declaration was provided by $76.6 \%$ of consumers in cluster $\mathrm{V}$. These people may be then defined by the term withdrawn sceptics; they constituted the least numerous group of respondents in the sample $-4.6 \%$.

\section{Conclusions}

The research results indicate the positive attitudes of the consumers studied towards all analysed modern solutions in the retail trade, in particular at the emotional level. They thereby confirm the hypothesis assumed in the introduction to this paper. What is worth emphasizing is the fact that it was observed that the very lack of knowledge of a given device or its non-use does not have to denote that the consumer has a negative attitude towards it. The very image of a specific facility and the benefits it brings causes positive reactions among 
them. The example here may be the relatively unknown but there was a positive perception of intelligent shopping trolleys. On the other hand a wide awareness of a given solution does not have to denote its common acceptance and its use now and in the future. Virtual advisers can be an example of this who tried to replace a direct, personal contact of a shop assistant with a consumer.

One of the methods of cluster analysis applied - Ward's method - for the purpose of obtaining more profound analysis of the obtained results - allowed a focus on the considerable lack of similarity amongst the consumers analysed. As a result of the analyses the dendrogram indicated many different clusters of consumers, which were eventually isolated into five relatively homogeneous groups of respondents. The largest group (40.1\%) consisted of the so-called "active innovators" characterised by the most positive attitude to the solutions analyzed and the most frequent use of this type of devices among all isolated clusters. The second largest group of respondents $(20.1 \%)$ and the second most favourable group to new technologies in the retail trade were the so-called "busy conformists". On the other hand the group of consumers who may be defined as "independent pragmatists" (17.9\% of the total respondents) were the example of a neutral attitude to the modern solutions proposed, which are selected depending on needs or necessity. The relatively big indifference tending towards negative attitudes in respect of solutions put forward was characterised by the subsequent isolated group of consumers - "careful realists" constituting $17.4 \%$ of the sample. They are not very keen on novelties, relying most of all on tested solutions. They need time to accept the suggested facilities. The "withdrawn sceptics" were at the opposite pole as compared to "active innovators". The "withdrawn sceptics" constituted the least numerous group of consumers analyzed (4.6\%). They are characterized by the biggest scepticism among all clusters, not only to modern solutions in the retail trade, but also to any novelties and changes. This is the oldest age group and relatively poorly educated, originating more frequently than others from small places. Probably such features are decisive in explaining the reasons for lack of their enthusiasm for modern solutions in the retail trade. The research results obtained should be interpreted with care as they are not representative for the entire population.

The research results and their analyses entail certain practical implications being potentially helpful for commercial companies in gaining a competitive advantage. As presented here consumers purchasing goods in retail outlets do not constitute a homogenous group. A new generation of consumers, a generation of current 18 years-olds, called the $\mathrm{Z}$ generation, the screen generation, just entering the market, will certainly expect the solutions in their commercial outlets as described in this article. While searching for goods and services essential for them they will not look around the shop and ask others where they are located, but stare at their smart-phones, tablets, screens and they will precisely follow the places displayed on these screens. On the other hand consumers sceptically oriented towards the solutions described here will certainly 
be convinced to use them when they are able to freely test them when the solutions adopted are adjusted to their education level and social competences and when they are able to rely on friendly and competent assistance from the staff in the retail outlet. Commercial enterprises willing to make increased profits from these solutions should care not only about the physical distribution of these devices in their retail outlets but also prepare sales personnel, particularly those responsible for customer service, for the role of an educator and promoter of the solutions implemented.

\section{References}

Albarracin, D., \& Shavitt S. (2018). Attitudes and Attitude Change. Annual Review of Psychology, 69, 299-327.

Biswas, A., \& Roy, M. (2018). Technology acceptance perception for promotion of sustainable consumption. Environmental Science and Pollution Research International, 25(7), 6329-6339. doi: 10.1007/s11356-017-0964-4

Bolton, R. N., Parasuraman, A., Hoefnagels, A., Migchels, N., Kabadayi, S., Gruber, T., \& Solnet, D. (2013). Understanding Generation Y and their use of social media: a review and research agenda. Journal of Service Management, 24(3), 245-267.

Brosdahl, D. J., \& Carpenter, J. M. (2011). Shopping orientations of US males: a generational cohort comparison. Journal of Retailing and Consumer Services, 18, 548-554.

Falkowski, A., \& Tyszka, T. (2009). Psychologia zachowań konsumenckich. Gdańsk: Gdańskie Wydawnictwo Psychologiczne.

Foscht, T., Schloffer, J., Iii, C. M., \& Chia, S. L. (2009). Assessing the outcomes of Generation-Y customers' loyalty. International Journal of Bank Marketing, 27(3), 218-241.

Goban-Klas, T., \& Sienkiewicz, P. (1999). Społeczeństwo informacyjne: szanse, zagrożenia, wyzwania. Kraków: Wydawnictwo Fundacji Postępu Telekomunikacji.

Gołąb-Andrzejczak, E. (2014). Lojalność w społeczeństwie informacyjnym na przykładzie "pokolenia Millennium", Marketing i Rynek, 11, 11-21.

Hoyer W. D., MacInnis D. J., \& Pieters R. (2013). Consumer behavior. Mason: SouthWestern College Learning.

Ito, Y. (1980, March). The Johoka Shakai approach to the study of communication in Japan. Keio Communication Review, 1, 3-12.

Knežević, B., Delić, M. (2017). Young consumers' perception of problems and usefulness of mobile shopping applications. Entrepreneurial Business and Economics Review, 5(1), 43-55. doi: 10.15678/EBER.2017.050103

Kucharska, B. (2014). Innowacje w handle detalicznym w kreowaniu wartości dla klienta. Katowice: Wydawnictwo Uniwersytetu Ekonomicznego w Katowicach.

Kushwaha, T., Ubeja, S., \& Chatterjee, A. S. (2017). Factors influencing selection of shopping malls: an exploratory study of consumer perception. Vision, 21(3), 274-283. doi: $10.1177 / 0972262917716761$ 
Lipowski, M. (2010). Zastosowanie technologii elektronicznych. In G. Sobczyk (Ed.), Zarządzanie sprzedaża w przedsiębiorstwie handlowym i usługowym (pp. 104-117). Warszawa: PWE.

Littman, S. (2008, May). Welcome to the new Millennials. Response Magazine.

Luceri, B., Sabbadin, E., \& Zerbini, C. (2017). Innovation in tradition: key success factors of new entrepreneurs in the retail trade. International Business Research, 10(12), 239-245. doi: 10.5539/ibr.v10n12p239

Maciejewski, G. (2016). Purchasing places of consumer goods in selected European countries. Acta Scientiarum Polonorum Oeconomia, 15(2), 87-101.

Maison, D. (2004). Utajone postawy konsumenckie. Gdańsk: Gdańskie Wydawnictwo Psychologiczne.

Migdał-Najman, K., \& Najman, K. (2013). Analiza porównawcza wybranych metod analizy skupień w grupowaniu jednostek o złożonej strukturze grupowej. Zarządzanie $i$ Finanse, 3, 179-194.

Nunally, J. C., \& Berstein, I.H. (1994). Psychometric theory. New York: McGraw-Hill.

Planet Retail RNG (2015, July 27). CEE regional overview 2015 - Retail Trends \& Forecasts.

Richard K. Miller \& Associates (2011). Consumer behavior 2011: millennial consumers. Loganville, GA: Richard K. Miller and Associates (RKMA).

Rudnicki, L. (2012). Zachowania konsumentów na rynku. Warszawa: PWE.

Samoggia, A., \& Nicolodi, S. (2017). Consumer's perception of fruit innovation. Journal of International Food \& Agribusiness Marketing, 29(1), 92-108. doi: 10.1080/08974438.2016.1266567

Seppanen, S., \& Gualtieri, W. (2012). The millenial generation. Washington, DC: National Chamber Foundation.

Stasiuk, K., \& Maison, D. (2014), Psychologia konsumenta. Warszawa: Wydawnictwo Naukowe PWN.

Taranko, T. (2017). Uwarunkowania postaw konsumentów wobec marek pochodzenia polskiego oraz marek pochodzenia zagranicznego. In R. Baran, B. Marciniak, T. Taranko (Eds.), Postawy konsumentów wobec marek pochodzenia polskiego i zagranicznego (pp. 23-27). Warszawa: Oficyna Wydawnicza SGH.

Trojanowski, M. (2013), Postawy konsumentów wobec sprzedaży wysyłkowej - ujęcie dynamiczne. Warszawa: WN Wydziału Zarządzania Uniwersytetu Warszawskiego.

Van den Berch, J., \& Behrer, M. (2012). Jak kreować marki, które pokocha pokolenie Y, Warszawa: Wydawnictwo Edgar.

Walesiak, M. (2004). Metody klasyfikacji. In. E. Gatnar, M. Walesiak (Eds.), Metody statystycznej analizy wielowymiarowej w badaniach marketingowych (pp. 344-347). Wrocław: Wydawnictwo Akademii Ekonomicznej im. Oskara Langego we Wrocławiu.

Walesiak, M. (2009). Analiza skupień. In. E. Gatnar, M. Walesiak (Eds.), Statystyczna analiza danych $z$ wykorzystaniem programu $R$ (407-421). Warszawa: Wydawnictwo Naukowe PWN.

Wojciszke, B. (2011). Psychologia społeczna. Warszawa: Wydawnictwo Naukowe Scholar. 